\title{
Simple models and concepts as tools for the study of sustained soil productivity in long-term experiments. I. New soil organic matter and residual effect of $P$ from fertilizers and farmyard manure in Kabete, Kenya
}

\author{
Bert H. Janssen
}

Received: 23 November 2009/Accepted: 9 September 2010 /Published online: 12 October 2010

(C) The Author(s) 2010. This article is published with open access at Springerlink.com

\begin{abstract}
The rough outcomes of a long-term experiment in Kenya were (re-)interpreted using simple models to find causes of success or failure with regard to sustained soil productivity. A two- pools model calculated the development of soil organic matter, and a practical equation estimated the residual effect of fertilizer P. Relative mineralization rate was 4 and $8 \%$ $\mathrm{y}^{-1}$ for original and newly formed soil organic carbon (SOC). Maize yielded 0.25 and $1.1 \mathrm{tha}^{-1}$ per $\mathrm{gkg}^{-1}$ of original and new SOC, respectively. Yields of fertilized maize increased initially as a result of increasing residual effects of applied $\mathrm{P}$, but decreased later presumably because SOC declined to below a critical level of $16 \mathrm{~g} \mathrm{~kg}^{-1}$. To maintain SOC above this level, about 10 tons of farmyard manure (dry matter) must be applied annually. Agronomic nutrient use efficiencies for fertilizer $\mathrm{N}$ and $\mathrm{P}$ were low, but the residual effect of $\mathrm{P}$ was high. The simple model outlined half a century ago adequately calculated build-up of new soil organic matter. The estimated residual effect of fertilizer $P$ explained increasing crop responses to repeated $\mathrm{P}$ applications. The absence of data on nutrient uptake
\end{abstract}

Responsible Editor: Johan Six.

B. H. Janssen $(\bowtie)$

Plant Production Systems,

Wageningen University \& Research Centre,

Wageningen, The Netherlands

e-mail: Bert.Janssen@wur.nl by the crop strongly limited the understanding of the experimental results.

Keywords Agronomic nutrient use efficiency · Kikuyu red clay · Physiological nutrient use efficiency · 'Young' soil organic matter
Abbreviations
A
Supply rate of New SOC
$\mathrm{A}_{\mathrm{FYM}}$
Supply rate of SOC newly formed
$\mathrm{A}_{\mathrm{rs}}$ from farmyard manure
As Supply rate of SOC newly formed from root and stubble
$\mathrm{A}_{\mathrm{rsij}} \quad$ Remaining quantity in Year $\mathrm{j}$ of $\mathrm{A}_{\mathrm{rs}}$
AEN agronomic efficiency of applied fertilizer $\mathrm{N}$
$\mathrm{AEP}_{2} \mathrm{O}_{5} \quad$ agronomic efficiency of applied fertilizer $\mathrm{P}_{2} \mathrm{O}_{5}$
$\mathrm{D}_{\mathrm{t}} \quad$ Decomposition of original SOC in Year $\mathrm{t}$
FYM Farmyard manure also: experimental treatment with annual additions of 5 tha ${ }^{1}{ }^{1}$ of FYM dry matter newly formed from annually applied FYM
FYMMinN N mineralized from soil organic matter
FYMMinP P mineralized from soil organic matter newly formed from annually applied FYM 
FYMN N present in FYM in forms as available to crops as fertilizer $\mathrm{N}$

FYMNP1 Experimental treatment with annual additions of 5 tha $^{-1}$ of FYM dry matter $+60 \mathrm{kgha}^{-1}$ fertilizer $\mathrm{N}+60 \mathrm{~kg}$ ha ${ }^{-1}$ fertilizer $\mathrm{P}_{2} \mathrm{O}_{5}$

FYMP $\quad P$ present in FYM in forms as available to crops as fertilizer $\mathrm{P}$

$\mathrm{k}$

$\mathrm{k}_{\Delta \mathrm{s}}$

NP

q

$\mathrm{PhE}$

REC

$\mathrm{REC}_{1}$

$\mathrm{REC}_{\mathrm{t}}$

$\mathrm{REC}_{\mathrm{nt}}$

RFYM Response (yield increase) to FYM

RFYMMinN Response (yield increase) to FYMMinN

RFYMMinP Response (yield increase) to FYMMinP

RFYMN Response (yield increase) to FYMN

RFYMP Response (yield increase) to FYMP

RN Response (yield increase) to input N

$\mathrm{RP} \quad$ Response (yield increase) to input $\mathrm{P}$

$\mathrm{RP}_{\mathrm{t}} \quad$ Response (yield increase) in year $\mathrm{t}$ to a single application of $\mathrm{P}$ in year 1

$\mathrm{RP}_{\mathrm{nt}} \quad$ Response (yield increase) in year $\mathrm{t}$ to $\mathrm{n}$ equally large applications of $\mathrm{P}$

RSDM Biomass of root and stubble

SOC Soil organic carbon

$\mathrm{SOC}_{\mathrm{li}} \quad$ left-over of initial SOC

$\triangle \mathrm{SOC} \quad$ Newly formed SOC

$\triangle \mathrm{SOCD}_{\mathrm{t}} \quad$ Decomposition of newly formed SOC in between Year $(\mathrm{t}-1)$ and Year $\mathrm{t}$

$\triangle \mathrm{SOC}_{\mathrm{FYM}} \quad$ SOC newly formed from FYM

$\triangle \mathrm{SOC}_{\mathrm{rstj}} \quad$ SOC newly formed at time $\mathrm{t}$ after $\mathrm{j}$ years of root and stubble additions

$\triangle$ YNP Response to $60 \mathrm{kgha}^{-1}$ fertilizer $\mathrm{N}+$ $60 \mathrm{kgha}^{-1}$ fertilizer $\mathrm{P}_{2} \mathrm{O}_{5}$

\section{Introduction}

The subject of sustainable agriculture does not only refer to continuing soil productivity, but also to the impacts of farming on the environment and to economic viability. Sustainability was described as the ability to maintain agricultural output in quantity and quality year after year without degradation; particularly in relation to environmental concerns (Barnett 1994). Sustainable agriculture integrates three main goals: environmental stewardship, farm profitability, and prosperous farming communities. These goals have been defined by a variety of disciplines and may be looked at from the vantage point of the farmer or the consumer. Sustainable agriculture refers to agricultural production that can be maintained without harming the environment (Wikipedia).

The topic of this paper, however, is narrowed down to sustained soil productivity, so to the function of soil to promote plant growth and specifically to the provision of plant available mineral nutrients.

Long-term experiments started before sustainability became the hot issue it is at present. As a consequence, the designs of these experiments were not directed, at least not explicitly, towards answering sustainability questions. Nevertheless, long-term experiments may provide, often after re-interpretation, important and sometimes surprising insights in current research problems.

It seems self-evident that the experimental design of long-term trials should not change over time. It is possible, however, that the treatments that would result in sustained productivity have not been included in the original set-up of the experiment. As a consequence the really desired management practices are not revealed, at least not in a direct and convincing way. It may also occur that the experimental design included treatments that originally were optimum, but that the requirements for sustained production have changed in course of time, e.g. because new crop varieties with higher yield potential or better nutrient use efficiency were introduced, or because the soil changed in response to the repeated treatments, for instance by build-up of soil organic matter or of the stock of phosphorus (P) in the soil. Under these conditions it is not prudent to stick to the original experimental design. Even the Rothamsted classical experiments have been modified in the past one and half century, for good reasons (Johnston 1994). 
There are situations, where soil productivity obviously cannot be sustained, e.g., in case processes such as erosion, salting-up, acidification, and the like occur. Under these circumstances, field trials likely would not exist for a long time. Hence, a study on long-term field experiments automatically precludes those conditions. Numerous papers spend special attention on the prominent role of soil organic matter with regard to sustainable soil productivity (Weil and Magdoff 2004). Soil organic matter and associated biological activities promote soil physical conditions, but their greatest effect on soil productivity likely often is brought about by the supply of $\mathrm{N}$ through mineralization as was already shown in the seventies (Hoogerkamp 1973).

The interpretation of rough experimental outcomes is facilitated by the use of models. The models should be simple because long-term field trials, having started before the development of information technology, lack sophisticated and detailed data logging. In the present paper, simple and already long-existing models are applied to (re-)analyze the outcomes of a long-term field experiment in Kenya. The trial had been set up to determine appropriate methods for maintaining and improving the fertility of the soil (Swift et al. 1994). The aim of the present paper is to demonstrate the surplus value of simple models in unraveling the longterm response of crops to farmyard manure (FYM) and fertilizer NP, especially in case quantities and kinds of available data are very limited.

The specific objectives were to find and understand the causes of success of some and of failure of other experimental treatments. The discussion is narrowed down to the following questions:

- What factors caused soil productivity decline?

- What were the critical values of the factors determining sustained production?

- Would it have been possible to foresee from the beginning which of the experimental treatments were to end up in unsustained soil productivity?

- What would be needed to change unsustained into sustained soil productivity?

The present paper focuses on effects of soil organic carbon (SOC), $\mathrm{N}$ and $\mathrm{P}$ on yields. The emphasis on these factors bears the risk of neglecting the role of other nutrients than $\mathrm{N}$ and $\mathrm{P}$ in the studies on sustained soil productivity. In the accompanying paper, the role (of the proportions) of the nutrients $\mathrm{N}, \mathrm{P}$ and $\mathrm{K}$ is considered. The general objective of both papers is to find ways for maximum nutrient use efficiency. Efficient use of nutrients serves the economical goals of the farmer and minimizes environmental burdens, and thus greatly contributes to sustainable agriculture.

\section{Materials and methods}

Summary description of the long-term experiment at Kabete, Nairobi, Kenya

A long-term trial was set up in Kabete, Nairobi, Kenya in a former coffee plantation on a Humic Nitisol (Kapkiyai et al. 1999). The results obtained between 1976 and 1991 have been published (Swift et al. 1994). The soil was described as a deep well-drained loam, low in total $\mathrm{P}$ and available $\mathrm{N}$, and adequate in $\mathrm{K}$. The paper shows a graph with the course of soil organic carbon (SOC) analyzed in the topsoil of $15 \mathrm{~cm}$. The treatments used were: control, 5 ton dry matter of farmyard manure $+60 \mathrm{kgN}+60 \mathrm{~kg} \mathrm{P}_{2} \mathrm{O}_{5}$ per ha per year (FYMNP1), and 10 ton dry matter of farmyard manure $+120 \mathrm{kgN}+120 \mathrm{~kg} \mathrm{P}_{2} \mathrm{O}_{5} \mathrm{P}$ per ha per year (FYMNP2). Maize stover was removed from the fields.

The authors also presented a graph with maize grain yields (three-year sliding averages) against time for four treatments: control, 5 ton FYM, $60 \mathrm{kgN}+$ $60 \mathrm{~kg} \mathrm{P}_{2} \mathrm{O}_{5}, 5$ ton $\mathrm{FYM}+60 \mathrm{kgN}+60 \mathrm{~kg} \mathrm{P}_{2} \mathrm{O}_{5}$. Severe drought resulted in total crop failure in 1984 , and hence in depressions of the sliding yield averages of 1983-1985.

As no data on rainfall were given in the original articles ((Swift et al. 1994; Kapkiyai et al., 1999), such data were derived from the grid system provided by the Climate Research Unit (CRU), University of East Anglia (New et al. 1999). They refer to coordinates $36.25 \mathrm{E}$, and $1.25 \mathrm{~S}$. The coordinates of Kabete are 36.41E and 1.15S (Kapkiyai et al. 1999). Data are shown in Table 1 for the periods between Julian days 81 and 160 (22 March and 9 June), being the main part of the Long Rains season which was used for maize growing in Kabete.

General remarks on time trends of yields and yield responses to fertilizer $\mathrm{N}$ and $\mathrm{P}$, and to FYM

In long-term experiments, successive yields often show a lot of variation in response to weather 
Table 1 Kabete. Rainfall between 22nd of March and 9th of June (Julian days 81-160, from CRU), observed maize yields (Swift et al. 1994), and calculated responses $\left(\mathrm{t} \mathrm{ha}^{-1}\right)$ to $\mathrm{NP}$, FYM and FYMNP1. Treatments are: Control, annual applications of $60 \mathrm{kgN}+$ $60 \mathrm{~kg} \mathrm{P}_{2} \mathrm{O}_{5}(\mathrm{NP})$, of 5 ton dry matter FYM), and of 5 ton dry matter of farmyard manure $+60 \mathrm{kgN}+60 \mathrm{~kg}$ $\mathrm{P}_{2} \mathrm{O}_{5}$ (FYMNP1). Data of rainfall and observed yields are three-year sliding averages

\begin{tabular}{|c|c|c|c|c|c|c|c|c|c|}
\hline \multicolumn{2}{|l|}{ Year } & \multirow[t]{2}{*}{ Rain, mm } & \multicolumn{4}{|c|}{ Observed yields, $\mathrm{t} \mathrm{ha}^{-1}$} & \multicolumn{3}{|c|}{ Calculated responses, $\mathrm{t} \mathrm{ha}^{-1}$} \\
\hline $\mathrm{AD}$ & Since start & & Control & NP & FYM & FYM NP1 & NP & FYM & FYM NP1 \\
\hline 1977 & 1 & 408 & 2.93 & 3.64 & 3.50 & 4.21 & 0.71 & 0.57 & 1.29 \\
\hline 1978 & 2 & 366 & 2.93 & 3.93 & 3.57 & 4.64 & 1.00 & 0.64 & 1.71 \\
\hline 1979 & 3 & 322 & 3.14 & 4.14 & 4.43 & 4.71 & 1.00 & 1.29 & 1.57 \\
\hline 1980 & 4 & 299 & 2.93 & 4.29 & 4.29 & 5.14 & 1.36 & 1.36 & 2.21 \\
\hline 1981 & 5 & 280 & 2.60 & 4.29 & 4.43 & 5.17 & 1.69 & 1.83 & 2.57 \\
\hline 1982 & 6 & 247 & 2.14 & 4.07 & 3.40 & 5.06 & 1.93 & 1.26 & 2.91 \\
\hline 1983 & 7 & 175 & 1.64 & 2.91 & 2.31 & 3.21 & 1.27 & 0.67 & 1.57 \\
\hline 1984 & 8 & 193 & 1.21 & 2.34 & 2.00 & 3.29 & 1.13 & 0.79 & 2.07 \\
\hline 1985 & 9 & 216 & 1.36 & 2.71 & 2.44 & 3.79 & 1.36 & 1.09 & 2.43 \\
\hline 1986 & 10 & 289 & 2.03 & 4.40 & 4.40 & 5.79 & 2.37 & 2.37 & 3.76 \\
\hline 1987 & 11 & 331 & 1.93 & 4.14 & 4.57 & 5.91 & 2.21 & 2.64 & 3.99 \\
\hline 1988 & 12 & 344 & 1.50 & 3.43 & 4.57 & 5.64 & 1.93 & 3.07 & 4.14 \\
\hline 1989 & 13 & 334 & 1.06 & 2.14 & 3.43 & 4.43 & 1.09 & 2.37 & 3.37 \\
\hline 1990 & 14 & 296 & 1.11 & 2.31 & 3.36 & 4.29 & 1.20 & 2.24 & 3.17 \\
\hline 1991 & 15 & 275 & 0.97 & 2.01 & 2.71 & 3.29 & 1.03 & 1.74 & 2.31 \\
\hline Mean & & 291 & 1.97 & 3.38 & 3.56 & 4.57 & 1.42 & 1.60 & 2.61 \\
\hline
\end{tabular}

conditions making the graphical representations of time trends rather confusing. Therefore it was preferred to plot cumulative yields instead of seasonal yields versus time. The cumulative yields were described by polynomials of the 2 nd and sometimes of the 3rd order forcing the regressions lines through the origin. These regression lines are only used to summarize the yields and to make it easier to read the graphs. The lines refer to the experimental periods only and are not extrapolated beyond those periods.

The crop response to NP was analyzed into an effect of $\mathrm{N}$, and into initial and residual effects of $\mathrm{P}$. Because no chemical data were available, a number of assumptions had to be made and simple models had to be applied. The procedure started with the calculation of the residual effect of input P. Next the agronomic efficiencies of fertilizer $\mathrm{P}$ and fertilizer $\mathrm{N}$ were assessed. The analysis of the response to FYM required an appraisal of the mineralization of $\mathrm{N}$ and $\mathrm{P}$ from the soil organic matter newly formed from the annually applied FYM. Using the values of the parameters found for the response to NP, it was possible to estimate the available quantities of $\mathrm{N}$ and $\mathrm{P}$ in FYM. The analysis of SOC development and crop responses was carried out with the following equations and models.
Build-up and mineralization of soil organic carbon $(\triangle \mathrm{SOC})$ formed from FYM and root and stubble

Exponential functions were applied to describe the time trends of soil organic carbon (SOC) content. The value of the negative exponent represents the relative decomposition rate $(\mathrm{k})$. The differences between the exponential functions of SOC in fields with and without application of farmyard manure (FYM) reflect the differences in quantities of newly formed SOC $(\triangle \mathrm{SOC})$ between these fields.

Next, the quantities of $\triangle \mathrm{SOC}$ were fitted to a somewhat modified version of an equation derived from the approach outlined some decades ago (Hénin et Dupuis 1945; Kortleven 1963). The reasoning is as follows. For a constant rate of supply of new SOC (A, $\mathrm{kgha}^{-1} \mathrm{y}^{-1}$ ) and a constant relative decomposition rate $\left(\mathrm{k}_{\Delta \mathrm{s}}, \mathrm{y}^{-1}\right)$ of newly formed SOC, the change of $\mathrm{Y}$ $(=\Delta \mathrm{SOC})$ is:

$\mathrm{dY} / \mathrm{dt}=\mathrm{A}-\mathrm{k}_{\Delta \mathrm{s}} \cdot \mathrm{Y}$

After integration, with the integration constant $Y_{0}=$ 0 , and reorganization:

$\Delta \mathrm{SOC}_{\mathrm{t}}=\left(\mathrm{A} / \mathrm{k}_{\Delta \mathrm{s}}\right) \cdot\left(1-\exp \left(-\mathrm{k}_{\Delta \mathrm{s}} \cdot \mathrm{t}\right)\right)$

where $\Delta \mathrm{SOC}_{\mathrm{t}}$ is $\Delta \mathrm{SOC}\left(\mathrm{kgha}^{-1}\right)$ at time t. 
In Kabete, the annual supply of new SOC, indicated by $\mathrm{A}$, consisted of two parts: $\mathrm{A}_{\mathrm{FYM}}$ derived from added farmyard manure, and $\mathrm{A}_{\mathrm{rs}}$ derived from remaining roots and stubble. The contribution by root and stubble $\left(\mathrm{A}_{\mathrm{rs}}\right)$ was calculated with

$\mathrm{A}_{\mathrm{rs}}=\mathrm{RSDM} \cdot C / \mathrm{DM} \cdot \mathrm{HC}$

where RSDM is the biomass of roots and stubble, $\mathrm{C} / \mathrm{DM}$ is the $\mathrm{C}$ fraction in crop $\mathrm{DM}$, and $\mathrm{HC}$ is the humification coefficient, which was defined as the fraction of RSDM that is still present in the soil after 1 year and behaves as soil organic matter (Kortleven 1963).

RSDM was estimated at half the maize grain yield. This was based on a maize biomass partitioning of 1000:1000:370 for grains, stover and roots (Janssen and De Willigen, 2006) and of 1000:2125:475 as used in Kabete (Kapkiyai et al. 1999). The estimate implies that $500 \mathrm{~kg}$ of RSDM approximately consist of $420 \mathrm{~kg}$ of roots and $80 \mathrm{~kg}$ of stover. The $\mathrm{C}$ fraction in crop DM usually is set at 0.45 , and the value of $\mathrm{HC}$ of root biomass at 0.3 (Janssen and De Willigen, 2006). In the highland tropical environment of Kabete, $\mathrm{HC}$ of root biomass must be less than 0.3 found in temperate climates. A value of 0.17 was used, based on the reasoning that the remaining organic matter must have a $\mathrm{C}: \mathrm{N}$ ratio of 10 in order to behave as soil organic matter of which $\mathrm{C}: \mathrm{N}$ is 10 . It implies that $\mathrm{HC}$ represents the fraction of plant biomass that can exactly turn into soil organic matter without causing net $\mathrm{N}$ mineralization or immobilization. Using $\mathrm{N}$ fractions of 0.005 in stover and 0.008 in roots (Janssen and De Willigen, 2006), $500 \mathrm{~kg}$ RSDM contains $3.76 \mathrm{~kg}$ of $\mathrm{N}$. If this $\mathrm{N}$ is incorporated in soil organic matter, it corresponds to $37.6 \mathrm{~kg} \mathrm{SOC}-\mathrm{C}$, which is 0.16711 (rounded 0.17 ) times the $225 \mathrm{~kg} \mathrm{C}$ present in $500 \mathrm{~kg}$ of RSDM.

Since grain yield varies from year to year, also $A_{r s}$ varies implying that Eq. 2 cannot be applied to $A_{r s}$. Instead the quantity built up from root and stubble $\left(\Delta \mathrm{SOC}_{\mathrm{tjrs}}\right)$ was calculated as the sum of the remainders of each $A_{r s}$. The remainders in Year $j$ of $A_{r s}$ applied in Year $i$, indicated as $A_{r s i j}$, was calculated as:

$\mathrm{A}_{\mathrm{rsij}}=\mathrm{A}_{\mathrm{rsi}} \cdot \exp \left(-\mathrm{k}_{\Delta \mathrm{s}} \cdot(\mathrm{j}-\mathrm{i})\right)$

The total quantity of SOC built up $\left(\Delta \mathrm{SOC}_{\mathrm{rstj}}\right)$ by the remaining amounts of $\mathrm{A}_{\mathrm{rsij}}$ is thus:

$$
\begin{aligned}
\Delta \mathrm{SOC}_{\mathrm{rstj}}= & \mathrm{A}_{\mathrm{rs} 1 \mathrm{j}}+\mathrm{A}_{\mathrm{rs} 2 \mathrm{j}}+\mathrm{A}_{\mathrm{rs} 3 \mathrm{j}}+\ldots . \\
& +\mathrm{A}_{\mathrm{rs}(\mathrm{j}-1) \mathrm{j}}
\end{aligned}
$$

It was assumed that $\mathrm{k}_{\Delta \mathrm{s}}$ had the same value for $\Delta \mathrm{SOC}_{\text {trsj }}$ as for $\Delta \mathrm{SOC}_{\mathrm{FYM}}$.

In Eqs. 2 and 5, the values of SOC are expressed in $\mathrm{kgha}^{-1}$. The SOC data in Kabete refer to $15 \mathrm{~cm}$ topsoil, with a volumic mass of $1.1 \mathrm{gcm}^{-3}$ (Swift et al. 1994). The conversion factor for SOC expressed in $\mathrm{kgha}^{-1}$ and SOC expressed in $\mathrm{gkg}^{-1}$ can therefore be set at 1650 .

When no new SOC is added, the decomposition of SOC in Year $t\left(D_{t}\right)$ can be calculated as the difference $\mathrm{SOC}_{(\mathrm{t}-1)}-\mathrm{SOC}_{\mathrm{t}}$. The calculation of the decomposition of new SOC $\left(\triangle S_{S O C D}\right)$ is a little more complicated because the annual additions of new SOC, at a rate of $\mathrm{A}$, make that $\Delta \mathrm{SOC}_{\mathrm{t}}$ is greater than $\left.\Delta \mathrm{SOCD}_{(\mathrm{t}-1)}\right)$. So, $\triangle \mathrm{SOCD}_{\mathrm{t}}$ was calculated as:

$\Delta \mathrm{SOCD}_{\mathrm{t}}=\mathrm{A}+\Delta \mathrm{SOC}_{(t-1)}-\Delta \mathrm{SOC}_{\mathrm{t}}$

Mineralization of $\mathrm{N}$ and $\mathrm{P}$ was supposed to follow mineralization of C (Gjettermann 2004). Assuming a $\mathrm{C}: \mathrm{N}$ of around 10 (Kapkiyai et al. 1998), the quantities of mineralized $\mathrm{N}$ were set at one tenth of the calculated quantities of decomposed $\mathrm{C}$ $\left(\triangle \mathrm{SOCD}_{\mathrm{t}}\right)$. Based on the assumption of $\mathrm{C}: \mathrm{P}$ of around 100 , mineralization of $\mathrm{P}$ was set at one hundredth of decomposed $\mathrm{C}$, in other words at one tenth of $\mathrm{N}$ mineralization.

\section{Residual response to added $\mathrm{P}$}

The response to applied $\mathrm{P}$ is composed of the effects of the most recent $\mathrm{P}$ application as well as of the residual effects of all the former $\mathrm{P}$ applications. A model with two P pools (Wolf et al. 1987) formed the basis for the calculation of the recent and residual effects of applied. In the model, $80 \%$ or more of applied $\mathrm{P}$ is allocated to a labile soil $\mathrm{P}$ pool and the other part to a stable soil $\mathrm{P}$ pool. In the year of application a part of the labile pool is absorbed by the crop, another part moves to the stable pool, and the remainder remains in the labile pool. In the next years always a same portion of the remaining labile pool is absorbed by the crop (residual effect). A practical equation (Janssen and Wolf 1988) that approximately summarizes the model was used in the present study to calculate the residual effect of applied $\mathrm{P}$. The ratio of crop absorbed $\mathrm{P}$ to applied $\mathrm{P}$ is the recovery fraction (REC). Because the labile pool decreases over time, the crop uptake of residual $\mathrm{P}$ decreases as well. The recovery fraction of fertilizer $\mathrm{P}$ applied at 
time 1 is calculated for the years after the year of application by:

$$
\begin{aligned}
\mathrm{REC}_{\mathrm{t}} & =\mathrm{REC}_{1} \cdot\left(1-\mathrm{LS}-\mathrm{REC}_{1}\right)^{(\mathrm{t}-1)} \\
& =\mathrm{REC}_{1} \cdot \mathrm{q}^{(t-1)}
\end{aligned}
$$

where $\mathrm{REC}_{1}$ stands for the recovery fraction of fertilizer $\mathrm{P}$ in Year 1, $\mathrm{REC}_{\mathrm{t}}$ for the residual recovery fraction in Year $\mathrm{t}$, and LS for the fraction of the labile soil $\mathrm{P}$ pool that moves to the stable soil $\mathrm{P}$ pool (all fractions $\mathrm{y}^{-1}$ or season ${ }^{-1}$ ), and $\mathrm{q}$ for (1-LS-REC 1 ) . When successively $n$ equally large quantities of $P$ have been added, the total recovery at time $t\left(\mathrm{REC}_{\mathrm{nt}}\right)$ consists of sum of the recovery of the last application $\left(\mathrm{REC}_{1}\right)$, the residual recovery of the last but one application $\left(\mathrm{REC}_{2}\right)$, etcetera. The residual recovery of the first application is then $\mathrm{REC}_{n}$. The sum of all the recovery fractions $\left(\mathrm{REC}_{\mathrm{nt}}\right)$ can be calculated as the sum of a geometrical progression:

$$
\begin{aligned}
\mathrm{REC}_{\mathrm{nt}} & =\mathrm{REC}_{1}+\mathrm{REC}_{2}+\mathrm{REC}_{3}+\ldots . \mathrm{REC}_{\mathrm{n}} \\
& =\mathrm{REC}_{1} \cdot\left(1-q^{n}\right) /(1-q)
\end{aligned}
$$

The crop yield increase brought about by input $\mathrm{P}$ is equal to the product of the input, the recovery fraction, and the physiological efficiency of $\mathrm{P}$ :

$$
\mathrm{RP}=\mathrm{IP} \cdot \mathrm{RECP} \cdot \mathrm{PhEP}=\mathrm{IP} \cdot \mathrm{AEP}
$$

In Eq. 9, RP is the grain yield response to $\mathrm{P}$ $\left(\mathrm{kgha}^{-1}\right)$, IP is the input of $\mathrm{P}\left(\mathrm{kgha}^{-1}\right)$, and PhEP the physiological efficiency of $\mathrm{P}$. PhP relates yield to uptake ( $\mathrm{kg}$ grain per $\mathrm{kg}$ nutrient taken up). It is used as a synonym for internal efficiency (IE). Because the acronym IE may lead to confusion as the letter 'I' would have two meanings (internal and input) in Eq. 9, the use of IE is avoided. The product RECP . $\mathrm{PhEP}$ is the increase in yield per $\mathrm{kg}$ of input $\mathrm{P}$, known as the agronomic efficiency (AEP). Combining Eqs. 8 and 9 , the crop response $\left(\mathrm{RP}_{\mathrm{nt}}\right)$ after $\mathrm{n}$ equally large inputs of $\mathrm{P}$, can be described by:

$$
\begin{aligned}
\mathrm{RP}_{\mathrm{nt}} & =\mathrm{IP} \cdot \mathrm{REC}_{\mathrm{nt}} \cdot \mathrm{PhEP} \\
& =\mathrm{IP} \cdot \operatorname{AEP} \cdot\left(1-\mathrm{q}^{\mathrm{n}}\right) /(1-\mathrm{q})
\end{aligned}
$$

From Eq. 8 it follows that the difference between $\mathrm{REC}_{n t}$ and $\operatorname{REC}_{(\mathrm{n}-1) \mathrm{t}}$ is equal to $\operatorname{REC}_{(\mathrm{t}-1)}$, and the difference between $\operatorname{REC}(\mathrm{n}-1) \mathrm{t}$ and $\mathrm{REC}_{(\mathrm{n}-2) \mathrm{t}}$ is equal to $\left(\mathrm{REC}_{(\mathrm{t}-2)}\right)$. The ratio of these differences was used to estimate the value of $q$ in Eq. $7: q=\left(\operatorname{REC}_{(t-1)}\right) / \operatorname{REC}_{(t-2)}$.
Because the crop responses (RP) are proportional to REC (provided PhEP is constant), also difference in crop response can be used for the estimation of $\mathrm{q}$.

Estimation of AEN and AEP, the agronomic efficiencies of applied $\mathrm{N}$ and $\mathrm{P}$

In the present experiment, the responses to the combined application of $\mathrm{N}$ and $\mathrm{P}$ were experimentally assessed, but the separate responses to $\mathrm{N}$ and $\mathrm{P}$ were not known. Assuming that any residual effect to applied $\mathrm{N}$ would be negligible, the difference between observed responses at time $(\mathrm{t}-1)$ and time $\mathrm{t}$ consists only of $\mathrm{RP}_{\mathrm{t}}$ and can be derived from the experimental yield data, except for $\mathrm{RP}_{1}$. The value of $\mathrm{RP}_{1}$ was calculated as $\mathrm{RP}_{2} / \mathrm{q}$, and next $\mathrm{AEP}$ as $\mathrm{RP}_{1} / \mathrm{IP}$ (Eq. 9 in reverse order). By subtracting $\mathrm{RP}_{1}$ from the observed first year response to NP, the response to $\mathrm{N}$ (RN) could be found. Next, AEN was calculated as RN/IN, where IN is the input of $\mathrm{N}$.

\section{Analysis of the response to FYM}

The response to FYM, denoted by RFYM, was considered to consist of RFYMminN and RFYMminP, being the responses to $\mathrm{N}$ and $\mathrm{P}$ mineralized from soil organic matter newly formed from the annually applied FYM, and of RFYMN and RFYMP being the responses to $\mathrm{N}$ and $\mathrm{P}$ originally present in FYM in forms as available to crops as fertilizer $\mathrm{N}$ and $\mathrm{P}$. It was assumed that for both forms of $\mathrm{P}$ the residual recovery was similar to that of fertilizer $P$.

First $\mathrm{N}$ and $\mathrm{P}$ mineralization (FYMMinN and FYMMinP) were estimated with the help of Eq. 6, and the corresponding crop responses, RFYMminN and RFYMminP, were calculated by multiplying FYMMinN and FYMMinP with the already found values of AEN OF AEP. These responses were subtracted from the experimentally observed data of RFYM, resulting in the combined responses to FYMN and FYMP standing for $\mathrm{N}$ and $\mathrm{P}$ present in FYM in forms as available to crops as fertilizer $\mathrm{N}$ and P. The sum of (RFYMN + RFYMP) can be found as:

$$
\begin{aligned}
(\text { RFYMN }+ \text { RFYMP })= & \text { FYMN } \cdot \text { AEN } \\
& + \text { FYMP } \cdot \text { AEP } \\
& \cdot\left(1-q^{n}\right) /(1-q)
\end{aligned}
$$


The unknowns in Eq. 11 are FYMN and FYMP. Various values of FYMN and FYMP were substituted in Eq. 11, till the best fit between 'observed' (RFYMN + RFYMP) and calculated (RFYMN + RFYMP) was found.

\section{Results}

Time trends of soil organic carbon (SOC) and maize yields

The observed maize grain yield data of Table 1 were read from an authors' graph (Swift et al. 1994). The responses to the treatments were calculated from these observed yields. The depression in the sliding averages of 1983-1985 shows up in the observed yields and also in the calculated responses.

To facilitate the reading of the graphs comparing the effects of the treatments on yield, the cumulative yields were calculated (Fig. 1), using the observed yields of years $1-6$ and $10-15$ of Table 1 . The yields of dry years 1983-1985 (Years 7. 8 and 9) were not included. Instead we calculated the cumulative yields for Years 7, 8 and 9 by extrapolation of the regression lines found for the cumulative yields of Years 1-6 (2nd order polynomials with $\mathrm{R}^{2}$ varying from 0.9976 to 0.9998 ). The cumulative yields in Fig. 1 were fitted to polynomials, 2 nd order for the control yields, and 3 rd order for the other treatments. All lines were forced through the origin. The negative quadratic term of the parabolic equation reflects the steady decrease of the control yields during the years of experimen- tation. The 3rd order polynomials reflect that the yields of maize receiving FYM or NP increased in the initial part and decreased in the later part of the experimental period. The decrease in yield started earlier in the NP than in the FYM treatments. By examining the relations between yield and SOC it was tried to discover why yields first increased and later decreased.

Figure 2 shows the course of SOC of FYMNP1 and Control treatments, for the seven points of time SOC was analyzed between 1976 and 1991, and the corresponding regression equations. The equation for SOC in the control plots points to a relative mineralization rate $(\mathrm{k})$ of $4 \%$ per year.

The difference between the two treatments was denoted by $\triangle \mathrm{SOC}$ and calculated, using the corresponding exponential regression equations and a value of $21.077 \mathrm{~g} \mathrm{~kg}^{-1}$ for $\mathrm{SOC}_{0}$. The thus calculated $\triangle \mathrm{SOC}\left(\mathrm{g} \mathrm{kg}^{-1}\right)$ consists of $\triangle \mathrm{SOC}_{\mathrm{FYM}}$ formed by the leftovers of applied FYM (Eq. 2) and $\Delta \mathrm{SOC}_{\mathrm{tjrs}}$, formed by root and stubble remainders (Eq. 5). In the experiment, the first application of root and stubble took place about 1 year later than the first application of FYM. Hence $\triangle$ SOC in Year 1 consisted of $\triangle \mathrm{SOC}_{\mathrm{FYM}}$ only and did not include $\Delta \mathrm{SOC}_{\mathrm{tjrs}}$. It was $0.335 \mathrm{~g} \mathrm{~kg}^{-1}$, as seen in Fig. 2.

The control treatment contains some $\Delta \mathrm{SOC}_{\text {trsi }}$ which was calculated with Eqs. 3 to 5, using the control yields of Table 1. First $\mathrm{SOC}_{\mathrm{li}}$ (standing for the left-over of the initial SOC) was calculated by subtraction of $\Delta \mathrm{SOC}_{\mathrm{rstj}}$ of the Control from the total SOC of the control treatments, which was equal to $21.077 \cdot \exp (-0.0398 \mathrm{t})$ as shown in Fig. 2. The
Fig. 1 Kabete. Cumulative maize yields as derived from Table 1. See text for explanation of Years 7-9

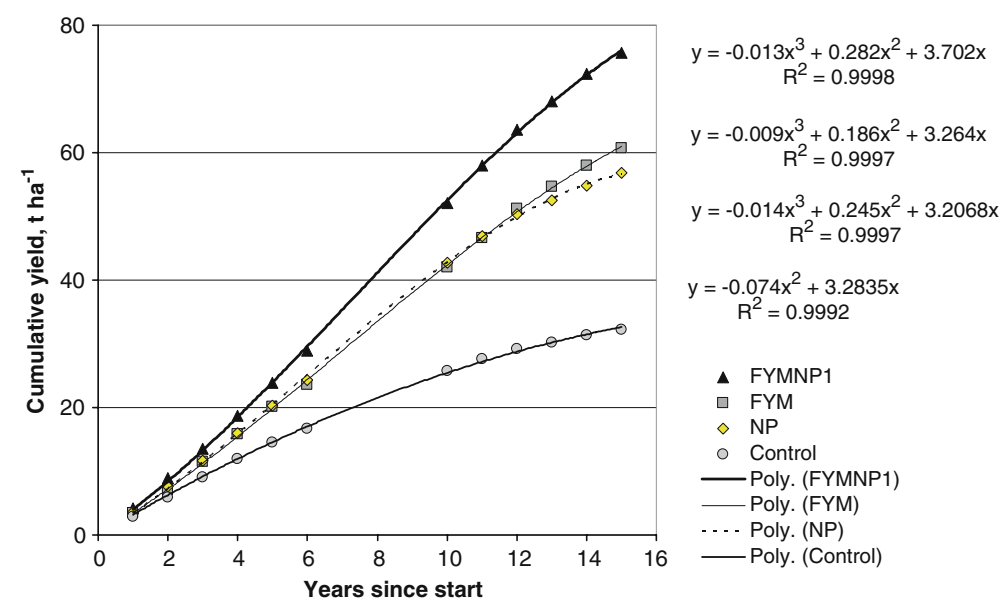




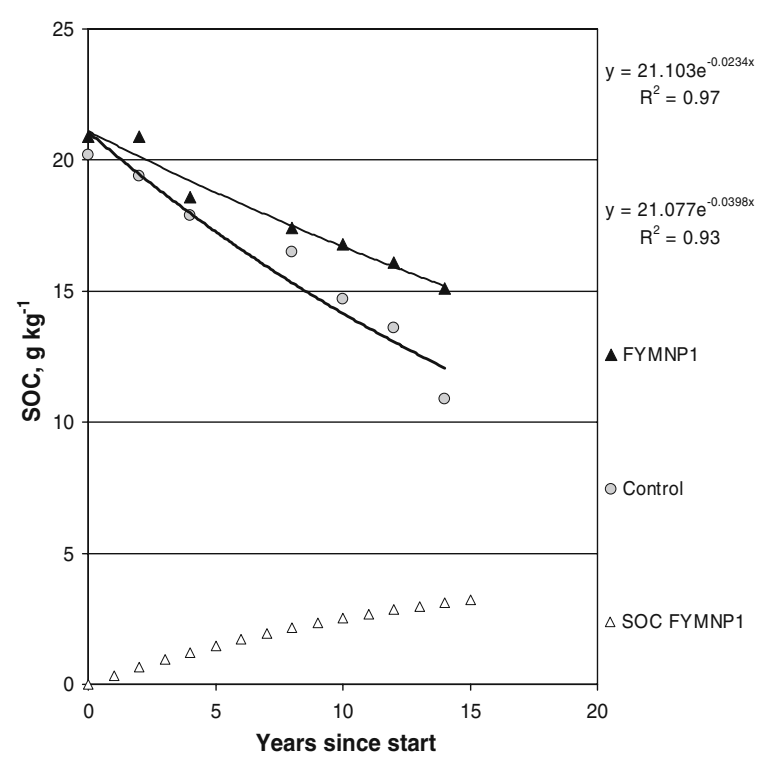

Fig. 2 Kabete. Course of soil organic carbon (SOC) of the long-term trial in Kabete (Swift et al. 1994), for the treatments FYMNP1 (5 ton dry matter of farmyard manure $+60 \mathrm{kgN}+$ $60 \mathrm{~kg} \mathrm{P}_{2} \mathrm{O}_{5}$ ) and Control. $\triangle \mathrm{SOC}$ was calculated as the difference between the exponential regression equations for SOC at FYMNP1 and Control. Upper equation refers to FYMNP1, lower equation to Control

relative decomposition rate of the thus calculated $\mathrm{SOC}_{\mathrm{li}}$ was $0.0418 \mathrm{y}^{-1}$, a little higher than that of total SOC of the control.

\section{Relations between yield and SOC}

In Fig. 3, the observed yields (from Table 1) have been plotted against the sliding averages of SOC, as calculated with $\mathrm{SOC}_{\mathrm{t}}=21.103 \mathrm{e}^{-0.0234 \mathrm{t}}$ for the treatment FYMNP1, and with $\mathrm{SOC}_{\mathrm{t}}=21.077 \mathrm{e}^{-0.0398 \mathrm{t}}$ for the control treatment. SOC of Treatment FYM was calculated as $\mathrm{SOC}_{\mathrm{t}}(\mathrm{FYMNP} 1)-\left(\Delta \mathrm{SOC}_{\mathrm{trsj}}(\mathrm{FYMNP} 1)-\right.$ $\Delta \mathrm{SOC}_{\text {trsj }}(\mathrm{FYM})$ ), and SOC of Treatment NP as $\mathrm{SOC}_{\mathrm{t}}($ Control $)+\left(\Delta \mathrm{SOC}_{\text {trsj }}(\mathrm{NP})-\Delta \mathrm{SOC}_{\text {trsj }}(\right.$ Control $\left.)\right)$. For the calculation of $\Delta \mathrm{SOC}_{\text {trsj }}$, Eq. 5 was used inclusive the dry years 1983, 1984 and 1985. Although the differences in $\Delta \mathrm{SOC}_{\text {trsj }}$ calculated in this way were not large, $0.02-0.28 \mathrm{gkg}^{-1}$ for (NPcontrol), and $0.02-0.20 \mathrm{~g} \mathrm{~kg}^{-1}$ for (FYMNP1-FYM), they were taken into account in Figs. 3 and 4.

Only the control treatment showed a clear relationship between yield and SOC. The regression line suggests that control yields increased by 0.25 tons $\mathrm{ha}^{-1}$ per $\mathrm{gkg}^{-1}$ SOC. Given a certain SOC value, the control yields were lower than the yields of the other treatments, but the relations are difficult to understand at first glance (Fig. 3). Highest SOC was found at the start of the experiment in 1977 (Fig. 2), but highest yields (Table 1) were obtained in 1988 with treatments FYMNP1 and FYM, and in 1982 and 1986 with treatment NP. These maximum yields were obtained at SOC of about $16 \mathrm{~g} \mathrm{~kg}^{-1}$. Between 1977 and 1986/88 yields increased although SOC decreased from 21 to about $16 \mathrm{~g} \mathrm{~kg}^{-1}$, but at SOC values $<16 \mathrm{~g} \mathrm{~kg}^{-1}$, yields sharply declined. This suggests that a SOC value of about $16 \mathrm{~g} \mathrm{~kg}^{-1}$ is critical.

The yield increase between 1977 and 1988 is ascribed, at least partly, to the growing quantity of new SOC $(\triangle \mathrm{SOC})$ for the treatments receiving FYM, and mainly to the residual effect of fertilizer $\mathrm{P}$ for the
Fig. 3 Kabete. Relation between Observed yields of maize (Table 1) and SOC, as estimated with regression equations of Figure 2. Data of both, yield and SOC, are 3 -year sliding averages. The sliding average yields of 1983, 1984 and 1985, which include the year 1984 with crop failure (see Table 1), were left out

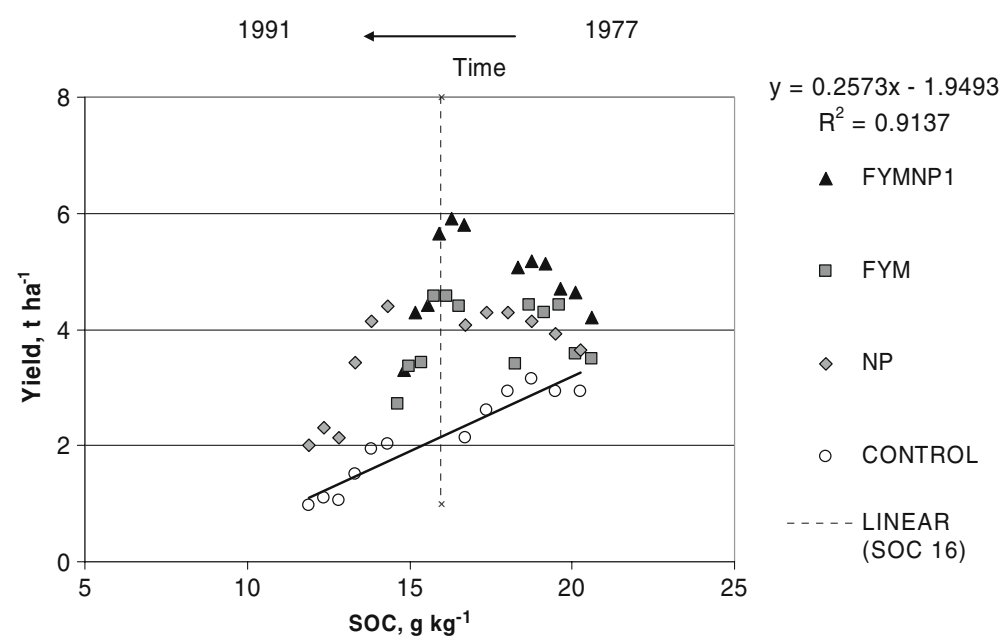


Fig. 4 Kabete. Relation between yield responses to FYM and FYMNP1 (Table 1) and 3-year sliding averages of calculated new SOC (1977-1988). Not included are yield responses of dry years (1983-1985). Data of 1989-1991 are not included in the regression analysis

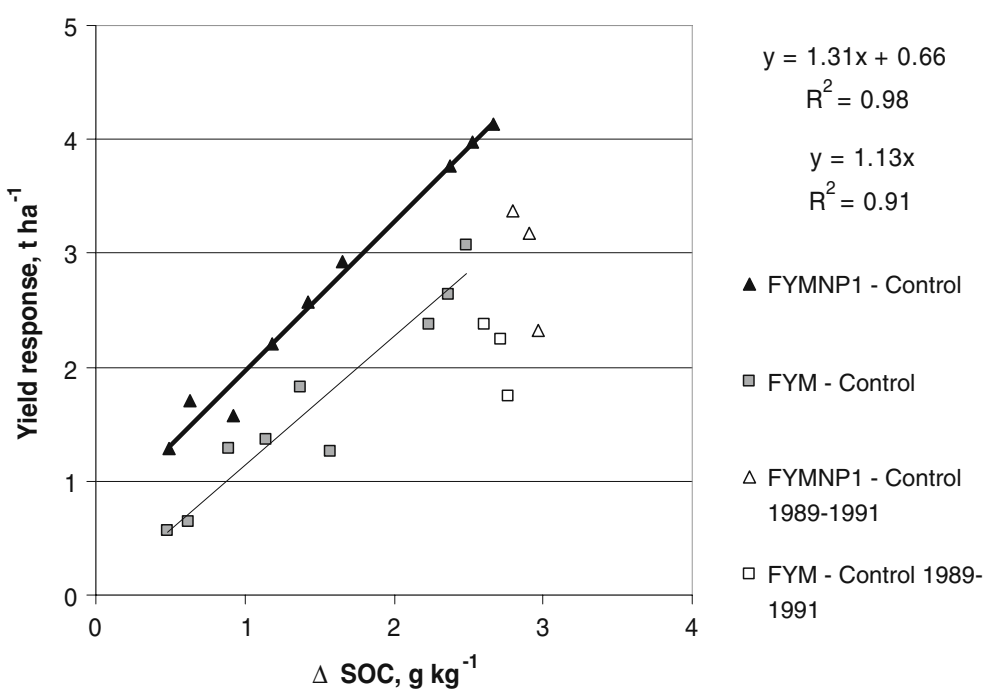

treatment NP. Figure 4 shows the yield responses to FYM (from Table 1) in relation to $\triangle \mathrm{SOC}$, as calculated in Fig. 2. For the treatment of FYM, $\triangle \mathrm{SOC}$ was set equal to $\triangle \mathrm{SOC}$ of FYMNP1 minus $\left(\Delta \mathrm{SOC}_{\text {trsj }}(\mathrm{FYMNP} 1)-\Delta \mathrm{SOC}_{\mathrm{trsj}}(\mathrm{FYM})\right)$, as explained above. The regression line for FYMNP1 in Fig. 4 lies about 0.7 tha $^{-1}$ higher, and is somewhat steeper than the line for FYM. This is considered the combined result of a direct effect of fertilizer $\mathrm{N}$ and $\mathrm{P}$ and $\mathrm{a}$ residual effect of $\mathrm{P}$. (see below). Comparison of Figs. 3 and 4 reveals that the yield response to $\triangle \mathrm{SOC}$ (about 1.1 ton per $\mathrm{gkg}^{-1}$ ) is four times as great as the yield response to SOC of the control treatment $\left(0.25\right.$ ton per $\left.\mathrm{gkg}^{-1}\right)$. The yield responses to $\triangle \mathrm{SOC}$ obtained in 1989-1991, however, are much lower. This may be related to the fact that total SOC was less than $16 \mathrm{~g} \mathrm{~kg}^{-1}$, as is shown below.

Analysis of the crop response to fertilizer NP and to FYM

By curve fitting the response to fertilizer NP was divided into a response to $\mathrm{N}$, and an initial and residual response to P. The dry years (1983-1985), and the years with the sudden yield decrease (1989-1991) were left out.

The response to NP ( $\triangle \mathrm{YNP})$ was estimated as the average of differences between the treatments NP and control, and between the treatments FYMNP1 and FYM. Considering the increasing crop responses to $\mathrm{NP}$ as a result of increasing effects of residual fertilizer $\mathrm{P}$, the value of $\mathrm{q}$ was estimated with Eq. 7 , and proved to be 0.85 . The rounded first-year crop response to $\mathrm{P}$ was estimated at 0.3 tha $^{-1}$ and the response to $\mathrm{N}$ at 0.39 tha $^{-1}$. The application rate was $60 \mathrm{~kg}$ for both $\mathrm{N}$ and $\mathrm{P}_{2} \mathrm{O}_{5}$. Hence, rounded values of the agronomic efficiencies were $6.5 \mathrm{~kg} \mathrm{~kg}^{-1}$ for AEN, and $5 \mathrm{kgkg}^{-1}$ for $\mathrm{AEP}_{2} \mathrm{O}_{5}$.

The response to FYM was estimated as the average of differences between the treatments FYM and control, and between the treatments FYMNP1 and NP. The increasing crop responses to FYM were seen as a result of residual $\mathrm{P}$, and of increasing quantities of $\mathrm{N}$ and $\mathrm{P}$ mineralized from newly formed soil organic matter. Mineralized $\mathrm{N}$ was set at one tenth of decomposed $\mathrm{C}$ $\left(\triangle \mathrm{SOCD}_{\mathrm{t}}\right)$, calculated with Eq. 6 , while $\Delta \mathrm{SOC}_{\mathrm{t}}$ was found via Eq. 2 and Eq. 5, with $\mathrm{k}_{\Delta \mathrm{s}}$ set at $0.0815 \mathrm{y}-{ }^{1}$. Mineralized $\mathrm{P}$ was set at one tenth of mineralized N. The quantities of mineralized $\mathrm{N}$ and $\mathrm{P}$ were multiplied with $6.5(\mathrm{AEN})$ and $4\left(\mathrm{AEP}_{2} \mathrm{O}_{5}\right)$, respectively, to assess RFYMminN and RFYMminP. These values were subtracted from the observed responses to FYM to find the sum of (RFYMN + RFYMP) in the successive years. Values of (RFYMN + RFYMP) were calculated with Eq. 11 for various values of FYMN and FYMP. The best fit obtained for FYMN was 35, and $\mathrm{FYMP}_{2} \mathrm{O}_{5}$ was $50 \mathrm{kgha}^{-1}$.

Using the derived values of AEN, AEP, q, FYMN and $\mathrm{FYMP}_{2} \mathrm{O}_{5}$ the responses to NP, FYM and FYMNP were calculated and compared to the observed responses (Fig. 5). The results of NP and FYMNP1 strongly deviate from the regression line for the years 1989-1991. The regression line for all treatments together is $y=1.0048 \mathrm{x}$, with $R^{2}=0.8889$. 
Fig. 5 Kabete. Relation between measured and modelled maize grain yield response to fertilizer NP, FYM and FYMNP. Regression equation refers to all points of the three treatments; $\mathrm{R}^{2}$ is 0.889 . Data of 1989-1991 are not included in the regression analysis

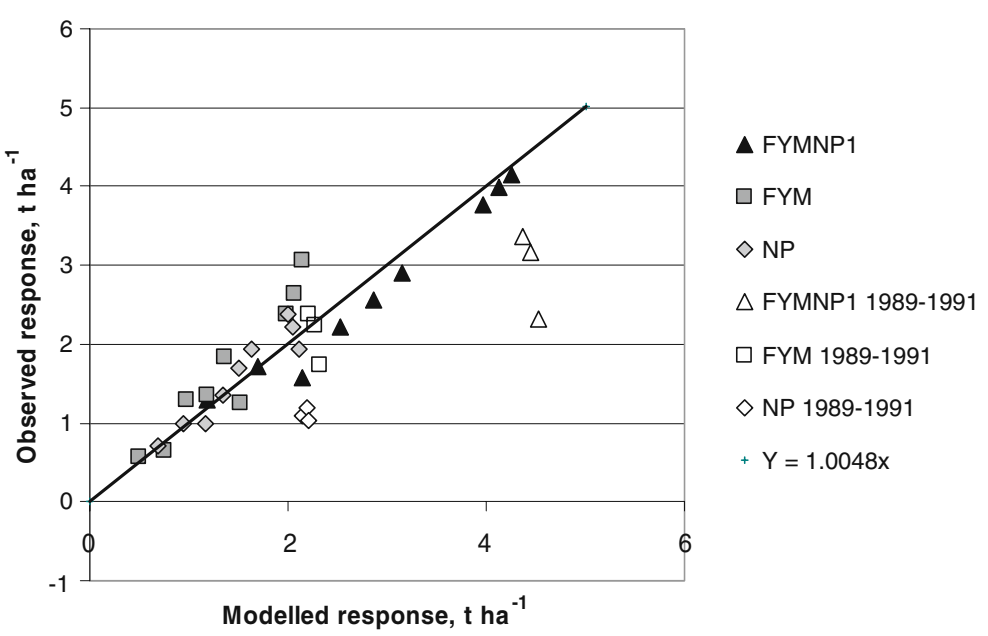

The ratios of observed to modelled values of the separate treatments were 1.06, 1.23 and 0.94 for NP, FYM and FYMNP1, respectively. Table 2 shows the sensitivity of model outcomes to changes of plus or minus $10 \%$ of the model parameters. The model was far less sensitive to a change of $\mathrm{N}$ parameters than to a change of $\mathrm{P}$ parameters, of which especially $\mathrm{q}$ strongly affected the outcome.

\section{Discussion}

Soil organic matter and yield

No simple relationship between crop yields and soil organic matter was found. The analysis of the Kabete experiment brought to light the important role of recently formed soil organic matter (Fig. 4) on maize production. The difference in the effect on yield between old and 'young' soil organic matter (YSOM) could be ascribed to differences in relative decomposition rates of about 4 and $8 \%$ per year, respectively, and to the input of P by FYM applications. Also in the Netherlands, relative mineralization rates and yields were related to YSOM rather than to total soil organic matter (Janssen, 1984). Compared to 'old' SOM, YSOM contains relatively much particulate organic matter which was strongly related to bean yields in Kabete ((Kapkiyai et al. 1999).

The SOC that in smallholder farms in Africa forms the difference in SOC observed between fields at different distances from the homestead (close, middistance, remote) may also be considered as YSOM.
In western Kenya, the yield increase brought about by YSOM varied between 2.5 and 6.6 tha $^{-1}$ per $\mathrm{g} \mathrm{kg}^{-1}$ total soil N (Vanlauwe et al. 2006), which comes down to $0.25-0.66 \mathrm{tha}^{-1}$ per $\mathrm{gkg}^{-1} \Delta \mathrm{SOC}$. These values are less than the 1.1 tha $^{-1}$ per $\mathrm{gkg}^{-1} \Delta \mathrm{SOC}$ found in Kabete (Fig. 4). Possible reasons for the differences are that the trials in western Kenya were carried out on farmers fields during the short rains, while the Kabete study was done on a research station and during the long rains. In the remote fields, the ratio of yield to SOC, which can be considered as 'old' soil organic matter, varied between 0.07 and

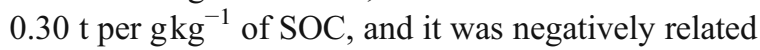
to soil texture: $y=-0.0006 \mathrm{x}+0.5036 ; \mathrm{R} 2=0.9338$, where $\mathrm{y}=\mathrm{yield} / \mathrm{SOC}$ and $\mathrm{x}$ is topsoil silt + clay content. In Kabete the ratio of yield to SOC of the control treatment was 0.15 in Year 1 and 0.09 in Year 15. The remote fields in western Kenya likely are better comparable to the Kabete situation in Year 15 than in Year 1. The values of 0.15 and 0.09 for Yield/ SOC would correspond with silt + clay contents of 589 and 689 , respectively. No data on soil texture in the Kabete trial were given, but the soil was described

Table 2 Responses of model outcomes (in \% of the original outcome) to $10 \%$ higher or lower values of the model parameters

\begin{tabular}{lcclll}
\hline $\begin{array}{l}\text { Parameter } \\
\text { Unit }\end{array}$ & $\begin{array}{l}\mathrm{AEN} \\
\mathrm{kgkg}^{1}\end{array}$ & $\begin{array}{l}\mathrm{AEP}_{2} \mathrm{O}_{5} \\
\mathrm{kgkg}^{1}\end{array}$ & $\begin{array}{l}\mathrm{FYMN} \\
\mathrm{kg}\end{array}$ & $\begin{array}{l}\mathrm{FYMP}_{2} \mathrm{O}_{5} \\
\mathrm{~kg}\end{array}$ & $\begin{array}{l}\mathrm{q} \\
\text { ratio }\end{array}$ \\
\hline Model value & 6.5 & 5 & 35 & 50 & 0.85 \\
$-10 \%$ & -2.5 & -7.5 & -0.7 & -3.1 & -16.0 \\
$+10 \%$ & 2.5 & 7.5 & 0.7 & 3.2 & 26.6 \\
\hline
\end{tabular}


as a loam (Swift et al. 1994) and also as a clay (Kapkiyai et al. 1999). Both textural classes may have silt + clay contents of 589 and $689 \mathrm{gkg}^{-1}$. They are generally found in the so-called Kikuyu Red clay in Kenya (Murage et al. 2000). Hence, the data on the productivity of 'young' and 'old' soil organic matter of the two studies (Vanlauwe et al. 2006 and the present paper) are not contradictory and can be considered as complementary.

\section{Critical level of SOC}

Notwithstanding several assumptions had to be made, it proved possible to estimate the maize grain yield response to applications of NP and FYM for the years 1-12. If, however, the $\mathrm{N}$ and $\mathrm{P}$ supplies would have been the only yield determining factor, yields would not have declined after about 12 years. Soil acidification and loss of soil structure have been mentioned as possible causes of yield decline (Swift et al. 1994), as well as depletion of $\mathrm{K}$ because stover was removed (Kapkiyai et al. 1999). It could also be possible that weather conditions had played a role. The years 1-15 hardly differed in temperature between Julian days 81 and 160 (average temperature ranged from $23.8^{\circ} \mathrm{C}$ to $25.4^{\circ} \mathrm{C}$ ). In the years $13-15$, rainfall was more than $275 \mathrm{~mm}$ (Table 1) and more than $40 \mathrm{~mm}$ per day on 1-3 days in this period. This alone cannot explain the sudden decline in yield response, as there were more years with such a rainfall.

There is an indication that in the Control treatment the relative rate of SOC decline $(\mathrm{k})$ increased after Year 8 , when SOC was about $16 \mathrm{gkg}^{-1}$ (Fig. 2), which is very unusual. According to exponential regression analysis, $\mathrm{k}$ apparently was $0.026\left(\mathrm{R}^{2} 0.9813\right)$ in years $0-8$, and $0.0661\left(\mathrm{R}^{2} 0.9516\right)$ in years $8-14$. Normally the relative decomposition rate of SOC decreases over time, because the remaining SOC becomes more resistant (Yang and Janssen 2000). The apparently increasing loss rate of SOC in the Control treatment after Year 8 could be the combined result of mineralization and erosion, but it should be recognized that these conclusions depend on very few data.

Hence, there are several indications in the present study that SOC must be $16 \mathrm{~g} \mathrm{~kg}^{-1}$ to avoid physical collapse of the soil. The requirement of $16 \mathrm{gkg}^{-1}$ of SOC seems severe, but it is not implausible. For instance, SOC was $24 \mathrm{~g} \mathrm{~kg}^{-1}$ in fields considered as productive by farmers, and $19 \mathrm{~g} \mathrm{~kg}^{-1}$ in fields considered as non-productive (Murage et al. 2000). Both values are even above the requirement of $16 \mathrm{~g}$ $\mathrm{kg}^{-1}$ found in the present study.

The SOC content required to avoid degradation is related to soil texture, especially to the fraction 0 $20 \mu \mathrm{m}$. The borderline for sustained fertility and productivity in semi-arid tropics was described by: SOC $=0.032(0-20 \mu)+0.87$ where SOC and fraction $(0-20 \mu)$ are both in $\mathrm{gkg}^{-1}$ (Feller and Beare 1997). Although Kabete is situated in a sub-humid rather than in a semi-arid area, this equation was applied, and disclosed that SOC of $16 \mathrm{~g} \mathrm{~kg}^{-1}$ is required for sustained productivity on a soil containing $473 \mathrm{~g} \mathrm{~kg}^{-1}$ of the fraction $0-20 \mu$, which is a 'normal' value for the so-called Kikuyu Red clay in Kenya (Murage et al. 2000) and can be found in loam as well as in clay soils. (The $473 \mathrm{~g} \mathrm{~kg}^{-1}$ for the fraction $0-20 \mu$ is of course less than the above mentioned contents of 589 and 689 for silt + clay, because silt + clay refers to the fraction $0-50 \mu$ ). Hence, the SOC requirement of $16 \mathrm{~g} \mathrm{~kg}^{-1}$ cannot be rejected on the basis of these calculations.

Theoretically, it would be possible to maintain SOC at $16 \mathrm{~g} \mathrm{~kg}^{-1}$ by application of huge amounts of farm-yard manure. Relative decomposition rates were $4 \%$ per year for old SOC and $8 \%$ per year for new SOC. To compensate for this decomposition, the annual addition of SOC must be at least $0.04 \cdot 16=$ $0.64 \mathrm{~g} \mathrm{~kg}^{-1}$. It was found that the SOC supply by 5 tons FYM dry matter per ha was $0.35 \mathrm{~g} \mathrm{~kg}^{-1}$. So, to keep SOC at $16 \mathrm{~g} \mathrm{~kg}^{-1}$, at least $5 \cdot 0.64 / 0.35$ or 9 tons FYM dry matter per ha must annually be applied. It likely is more because the relative decomposition rate will be more than 0.04 . An addition of 10 tha $^{-1}$ plus $120 \mathrm{kgN}$ and $120 \mathrm{~kg} \mathrm{P}_{2} \mathrm{O}_{5}$ proved enough to keep SOC above $16 \mathrm{~g} \mathrm{~kg}^{-1}$ (Swift et al. 1994). Another option than FYM application is the inclusion of artificial pastures, during e.g. 5 years, in a rotation with arable crops. It is likely that grasses, used as (live) mulch in the former coffee fields, have greatly contributed to the rather high SOC content of about $21 \mathrm{~g} \mathrm{~kg}^{-1}$ that was present at the start of the long-term trial in Kabete.

Contribution of $\mathrm{N}$ and $\mathrm{P}$ to treatment effects of continued application of FYM

The supplies of directly available $\mathrm{N}$ and $\mathrm{P}_{2} \mathrm{O}_{5}$ were indirectly estimated at 35 and $50 \mathrm{~kg}$ in 5 tons FYM 
dry matter. It was also found that $\mathrm{A}_{\mathrm{FYM}}$, the annual addition of SOC brought about was $0.35 \mathrm{~g} \mathrm{~kg}^{-1}$ or $577.5 \mathrm{kgha}^{-1}$. Assuming C:N is 10 and $\mathrm{C}: \mathrm{P}$ is 100 , this $\mathrm{A}_{\mathrm{FYM}}$ corresponds to $58 \mathrm{kgN}$, and $5.8 \mathrm{~kg} \mathrm{P}$ or $13.2 \mathrm{~kg} \mathrm{P}_{2} \mathrm{O}_{5}$. Together 5 tons FYM dry matter would have contained $93(=35+58) \mathrm{kgN}$ and $63(=50+13)$ $\mathrm{kg} \mathrm{P}_{2} \mathrm{O}_{5}$, which comes down to $19 \mathrm{kgN}$ and $13 \mathrm{~kg}$ $\mathrm{P}_{2} \mathrm{O}_{5}$ or $5.5 \mathrm{~kg} \mathrm{P}$ per ton FYM dry matter. These values are equal $(\mathrm{N})$ or somewhat below $(\mathrm{P})$ the maximum values found in Central Kenya (Lekasi et al. 2003). It may imply that the FYM used in the Kabete trial was of good quality, or that the estimates made are somewhat too high. We had assumed that AEN and AEP of FYMN and FYMP were equal to those of chemical fertilizer. It is however possible that they are somewhat higher because the $\mathrm{N}$ and $\mathrm{P}$ from FYM are released more gradually and hence they are perhaps less prone to leaching $(\mathrm{N})$ or fixation $(\mathrm{P})$. Anyhow, the estimates for AEN of 6.5 and for $\mathrm{AEP}_{2} \mathrm{O}_{5}$ of 5 are low, which may be due to a low recovery fraction or to a low physiological nutrient efficiency. The latter means that growth conditions were not optimal or that the genetic potential of the used cultivar was modest. The estimated value of $\mathrm{q}$, standing for (1-LS-REC1), is 0.85 , which implies that $\mathrm{REC}_{1}$ cannot exceed 0.15 . Also LS is small compared to standard value of 0.2 (Wolf et al., 1987). It follows that the residual effect of fertilizer P is strong, and this agrees with findings on similar soils in south-western Kenya (Van der Eijk et al. 2006).

In Table 1, the average difference in yield between NP and Control is 1.42, greater than the difference of 1.01 between FYMNP1 and FYM, which might be a consequence of diminishing returns. According to the estimates made, FYM provided $35 \mathrm{kgN}$ and $50 \mathrm{~kg}$ $\mathrm{P}_{2} \mathrm{O}_{5}$ in available form, so FYMNP1 provided $95 \mathrm{~kg}$ $\mathrm{N}$ and $110 \mathrm{~kg} \mathrm{P}_{2} \mathrm{O}_{5}$. It is quite well possible that AEN decreased between the rates of 35 and 95, and $\mathrm{AEP}_{2} \mathrm{O}_{5}$ between the rates of 50 and 110 . Unfortunately, the variability in yields and the lack of (chemical) data did not allow for such a differentiation in $\mathrm{AEN}$ and $\mathrm{AEP}_{2} \mathrm{O}_{5}$. In Fig. 5 the points of FYMNP1 are generally below the general regression line, implying that the modelled yield responses were somewhat too high, possibly because diminishing returns were not included in the model calculations for FYMNP1.

The increasing responses to the treatments NP, FYM and FYMNP1 are seen as a result of the strong residual effects of $P$. This gradual increase could be observed. Another but not visible consequence is that the relative contributions of $\mathrm{N}$ and $\mathrm{P}$ to the yield increase likely have changed in the course of time. According to the model calculations, $\mathrm{N}$ and $\mathrm{P}$ had about an equal effect on yield response in the first year, but after 10 years the effect of $P$ was 3-4 times as big as the effect of $\mathrm{N}$ (Table 3). Unbalanced NP proportions may have led to $\mathrm{N}$ deficiency. An additional effect is that the soil gradually gets $\mathrm{P}$ saturated which may lead to leaching and environmental pollution. This has happened in various parts of Europe and North America, but likely also in homesteads and corrals in African farms.

Simple models as alternatives to long-term experiments?

Long-term experiments are expensive and the question arises whether the insights obtained from such trials could not have been acquired with less expensive means. In hindsight, 10 years would have been sufficient to predict, on the basis of the relations in Fig. 2, that after about 12 years SOC would become less than $16 \mathrm{~g} \mathrm{~kg}^{-1}$ in the FYMNP1 treatment, but it is not likely that anybody would have foreseen that this would result in the yield decline shown in Fig. 4. Hence, the simple models used do not suffice to estimate the yield trend after 12 years; instead long-term experiments are needed.

In the Kabete trial, no chemical analysis of the crops was made. Any deficiency, e.g. of $\mathrm{K}$, could not be identified. For a good understanding of the results of long-term (fertilizer) trials, data on the uptake by the crop of the other nutrients are indispensable. Such information, however, very often is not available, likely because the costs involved in chemical analysis of crops have been prohibitive. Missing this crux in

Table 3 Subdivision of the crop responses to the treatments NP, FYM and FYMNP1 into a fraction caused by $\mathrm{N}$ and a fraction caused by $\mathrm{P}$

\begin{tabular}{lllllllll}
\hline Year & $\mathrm{NP}$ & & & \multicolumn{2}{l}{ FYM } & & \multicolumn{2}{l}{ FYMNP1 } \\
\cline { 2 - 3 } & $\mathrm{N}$ & $\mathrm{P}$ & $\mathrm{N}$ & $\mathrm{P}$ & & $\mathrm{N}$ & $\mathrm{P}$ \\
\hline 1 & 0.57 & 0.43 & 0.49 & 0.51 & 0.53 & 0.47 \\
10 & 0.20 & 0.80 & 0.24 & 0.76 & 0.22 & 0.78 \\
\hline
\end{tabular}


the scientific interpretation of the anyhow expensive long-term field trials may, however, imply higher, although not directly visible, costs. The absence of data on nutrient uptake by the crop has restricted the understanding of the experimental results and by that the value of this long-term experiment in Kabete.

\section{Conclusions}

With regard to the research methods used, it is concluded that, given the limited available data, the present analysis and understanding of the yield trends in Kabete would not have been obtained without the use of simple models. The relations between soil organic matter and maize yield in Kabete could adequately be described by the simple approach outlined long ago (Hénin et Dupuis 1945; Kortleven 1963) for the calculation of newly formed soil organic matter (Eq. 2). The equation used for the calculation of the residual effect of fertilizer $\mathrm{P}$ helped to explain the increasing yields in experimental units with repeated $\mathrm{P}$ applications. The graphs of cumulative yields or yield responses versus time simplified the illustration of treatment effects and time trends in the long-term experiments.

In general, the crop responses to $\mathrm{N}$ and $\mathrm{P}_{2} \mathrm{O}_{5}$ (agronomic nutrient use efficiencies) were low, but the residual effect of applied $\mathrm{P}$ was high.

The cause of declining crop production and declining responses to fertilizer and FYM in Kabete after about 12 years most likely was the decline of SOC (soil organic carbon) content to values below $16 \mathrm{~g} \mathrm{~kg}^{-1}$. To keep SOC above this value, around 10 tons of FYM dry matter must annually be applied.

Open Access This article is distributed under the terms of the Creative Commons Attribution Noncommercial License which permits any noncommercial use, distribution, and reproduction in any medium, provided the original author(s) and source are credited.

\section{References}

Barnett V (1994) Statistics and the long-term experiments: past achievements and future challenges. In: Leigh RA, Johnston AE (eds) Long-term experiments in agricultural and ecological sciences. CAB International, Wallingford UK, pp 165-183
Feller C, Beare MH (1997) Physical control of soil organic matter dynamics in the tropics. Geoderma 79:69-116

Gjettermann B (2004) Modelling P dynamics in soil- decomposition and sorption. Technical report. Concepts and User Manual. DHI Water and Environment. The Royal Veterinary and Agricultural University, Denmark, http://orgprints.org/ 5388/1/5388.pdf

Hénin S, Dupuis M (1945) Essai de bilan de la matière organique du sol. Ann Agron 15:17-29

Hoogerkamp M (1973) Accumulation of organic matter under grassland and its effects on grassland and on arable crops. Agricultural Research Reports 806. Wageningen, The Netherlands, p 24

Janssen BH (1984) A simple method for calculating decomposition and accumulation of "young" soil organic matter. Plant Soil 76:297-304

Janssen BH, De Willigen P (2006) Ideal and saturated soil fertility as bench marks in nutrient management. 1 . Outline of the framework. Agric. Ecosyst Environ 116:132-146

Janssen BH, Wolf J (1988) A simple equation for calculating the residual effect of phosphorus fertilizers. Fertilizer Research 15:79-87

Johnston AE (1994) The Rothamsted classical experiments. In: Leigh RA, Johnston AE (eds) Long-term experiments in agricultural and ecological sciences. CAB International, Wallingford UK, pp 9-37

Kapkiyai JJ, Karanja NK, Woomer PL, Qureshi JN (1998) Soil organic carbon fractions in a long-term experiment and the potential for their use as a diagnostic assay in highland farming systems of Central Kenya. Afr Crop Sci J 6:19-28

Kapkiyai JJ, Karanja NK, Qureshi JN, Smithson PC, Woomer PL (1999) Soil organic matter and nutrient dynamics in a Kenyan nitisol under long-term fertilizer and organic input management. Soil Biol Biochem $31: 1773-1782$

Kortleven J (1963) Kwantitatieve aspecten van humusopbouw en -afbraak. Versl Landbouwk Onderz 69.1. Pudoc Wageningen, The Netherlands, p 109

Lekasi JK, Tanner JC, Kimani SK, Harris PJC (2003) Cattle manure quality in Maragua District, Central Kenya: effect of management practices and development of simple methods of assessment. Agric Ecosyst Environ 94:289-298

Murage EW, Karanja NK, Smithson PC, Woomer PL (2000) Diagnostic indicators of soil quality in productive and non-productive smallholders' fields of Kenya's Central Highlands. Agric Ecosyst Environ 79:1-8

New M, Hulme M, Jones PD (1999) Representing twentieth century space-time climate variability. Part I: Development of a 1961-1990 mean monthly terrestrial climatology. J Climate 12:829-856

Swift MJ, Seward PD, Frost PGH, Qureshi JN, Muchena FN (1994) Long-term experiments in Africa: developing a database for sustainable land use under global change. In: Leigh RA, Johnston AE (eds) Long-term experiments in agricultural and ecological sciences. CAB International, Wallingford UK, pp 229-251

Van der Eijk D, Janssen BH, Oenema O (2006) Initial and residual effects of fertilizer phosphorus on soil phosphorus and maize yields on phosphorus fixing soils. A case study 
in south-west Kenya. Agriculture. Ecosystems and Environment 116:104-120

Vanlauwe B, Tittonell P, Mukalama J (2006) Within-farm soil fertility gradients affect response of maize to fertiliser application in western Kenya. Nutr Cycl Agroecosyst 76:171-182

Weil RR, Magdoff F (2004) Significance of soil organic matter to soil quality and health. In: Magdoff F, Weil RR (eds)
Soil organic matter in sustainable agriculture. CRC Press, Boca Raton, Florida, pp 1-43

Wolf J, De Wit CT, Janssen BH, Lathwell DJ (1987) Modeling long-term crop response to fertilizer phosphorus. I. The model. Agron J 79:445-451

Yang HS, Janssen BH (2000) A mono-component model of carbon mineralization with a dynamic rate constant. Eur J Soil Sci 51:517-529 